\title{
Perros en el paraíso: la influencia de la filosofía cínica en la construcción del mito del buen salvaje
}

\author{
Bernat CASTANY PRADO \\ Universidad de Barcelona \\ bcastany@ub.edu
}

\section{RESUMEN}

Este trabajo analiza la influencia de la filosofía cínica en la construcción del mito del buen salvaje. En la primera parte se estudia cuál era el conocimiento de dicha corriente filosófica durante el siglo XVI y cómo la impronta cínica de la obra de Erasmo, Moro o Montaigne pudo influir en el modo en que Europa se enfrentó a la cuestión del indígena americano. En la segunda parte se estudian qué motivos cínicos pudieron influir en la construcción del mito del buen salvaje.

Palabras clave: literatura colonial, crónicas, indígenas, cinismo, buen salvaje.

Dogs in the paradise: The influence of the cynical philosophy in the construction of the myth of the good savage

\begin{abstract}
This paper studies the influence of cynic philosophy in the construction of the myth of the good savage. In the first part it studies the importance of cynicism in the XVI century and how the cynic influence of Erasmus, More and Montaigne was fundamental to the way that Europe approached the American indigenous. In the second part it studies the cynic motives that could have influenced in the construction of the myth of the good savage.
\end{abstract}

Key words: Colonial literature, Chronicles, Indigenous, Cynism, Noble savage.

SUMARIO: Introducción. 1. La filosofía cínica y el Renacimiento. 2 .Motivos cínicos en el mito del buen salvaje. Conclusión.

Este trabajo forma parte de un conjunto de tres artículos que estudian la influencia de las filosofías helenísticas -epicúrea, cínica y escéptica- en la 
formulación moderna del mito del buen salvaje. ${ }^{1}$ Aunque a priori parece imposible añadir nada nuevo, lo cierto es que apenas existen estudios sobre la influencia que estas filosofías ejercieron en el modo en que Europa tematizó el mundo indígena. Este silencio sorprende cuando se advierte que el naturalismo epicúreo, el hipernaturalismo cínico y el antiintelectualismo escéptico fueron enormemente influyentes para los autores renacentistas. ${ }^{2}$ Aunque sea difícil estudiar por separado la influencia de dichas escuelas filosóficas, este artículo se ocupa, fundamentalmente, del papel que el cinismo pudo cumplir en la reformulación moderna del buen salvaje. En la primera parte, estudiaremos la importancia que el cinismo tuvo en la época de la conquista y colonización de América, y, en la segunda, analizaremos cómo algunas de las principales ideas cínicas pueden ser reconocidas entre el cúmulo de tópicos y motivos que suelen asociarse a dicha figura.

\section{La filosofía cínica y el Renacimiento}

La filosofía cínica, surgida en el contexto de crisis y de multiculturalidad que caracterizó la época helenística, no muy diferente, por cierto, al de la Europa

${ }^{1}$ Dichos artículos son "Cerdos en el paraíso: La influencia de la filosofía epicúrea en la construcción del mito del buen salvaje" (2013:279-291) y "Asnos en el paraíso: La influencia de la filosofía escéptica en la construcción del mito del buen salvaje" (en prensa).

${ }^{2}$ Cabe preguntarse, por qué, habiendo tantos indicios, no existen apenas estudios al respecto. Como suele suceder, este vacío teórico se debe a múltiples causas, algunas de corte ideológico o religioso. Destaquemos, para empezar, la caricaturización que los padres de la Iglesia llevaron a cabo de las filosofías helenísticas, cínica, epicúrea y escéptica, no así de la estoica y la neoplatónica, por considerarlas incompatibles con la doctrina o la sensibilidad cristianas. Tanto es así que, aunque el Renacimiento intentó recuperarlas y cristianizarlas, el estigma resultó ser tan profundo que no lograron rehabilitarse más que parcialmente. Por si esto no fuese suficiente, este cinismo cristianizado cayó de nuevo en el olvido con el advenimiento de la modernidad, racionalista y cientificista, cuyo progresismo era totalmente incompatible con el hipernaturalismo cínico (por no hablar del relativismo escéptico y el naturalismo epicúreo). Asimismo, el hecho de que el cinismo antiguo fuese "más una actitud vital ejemplificada inolvidablemente en tres o cuatro figuras señeras que un sistema o una escuela filosófica original" (García Gual, 1996: 11) le valió ser desatendido por la sensibilidad filosófica propia de la modernidad, que sólo consideró verdaderamente "filosóficos" aquellos autores que elaboraban sistemas. Finalmente, la condición voluntariamente ágrafa del cinismo, que llevó a que sus formas de expresión más habituales fuesen la anécdota, el apotegma o, incluso, el chiste, no sólo dificultó su transmisión, sino también su inclusión entre las expresiones filosóficas dignas de ser tenidas en cuenta por los autores modernos. Sobre la marginación de la filosofía cínica durante la época moderna, véase el capítulo "La constelación cínica", incluido en Las sabidurías de la antigüedad. Contrahistoria de la filosofia, de Michel Onfray (2008:131-142). 
renacentista, propugnó un hipernaturalismo que rechazaba las supuestas virtudes de la civilización para proponer una vía de ascetismo extremo que había de llevar al que la practicase a una felicidad entendida en términos de radical autonomía. Dicho ascetismo no sólo incluía el rechazo de las comodidades de la vida civilizada vestían un jubón de paño tosco, bastón de peregrino, no poseían casa propia, llevaban una vida frugal- ${ }^{3}$ sino también de todas las convenciones que, según ellos, caracterizaban la vida civilizada -sexuales, políticas, dietéticas-. ${ }^{4}$ El rechazo cínico de la civilización era tan radical que no sólo criticaba las convenciones sociales, sino, incluso, la humanidad misma, como prueba el hecho de que Diógenes de Sínope, según afirma Plutarco, rechazase el uso del fuego y se expusiese "al peligro en combate contra un pulpo crudo para que nuestra vida se aproxime a la de los animales" (Sobre comer carne, I, vi, § 995 c-d, t. IX, p. 385-386). ${ }^{5}$ Por si esto no fuese suficiente, los cínicos llegaron a ver en animales como el perro o el ratón un auténtico modelo de vida filosófica, frugal, autárquica y feliz. ${ }^{6}$ No es de extrañar, pues, que estos filósofos asumiesen el calificativo de "perros", que es, precisamente, la etimología del término "cínico". "A hora bien, del mismo modo que el cerdo de los epicúreos no era el cerdo obeso de la producción cárnica industrial de la era moderna, sino, más bien, un cerdo semejante al jabalí, admirable por su modo de vida libre y natural, el perro del que hablaban los cínicos, no era un perro

3 "Fue el primero, según Diocles, que duplicó el palio, sin llevar otra ropa, y que tomó báculo y zurrón.” (Laercio, VI, i, § 8, p. 137)

4 Sobre el rechazo cínico de las convenciones dietéticas, higiénicas y sexuales, recuérdese que Diógenes de Sínope "solía hacer todas las cosas en público, tanto las de Ceres cuanto las de Venus, valiéndose de estos argumentos: "Si el comer no es absurdo alguno, tampoco lo será comer en el foro. Es así que el comer no es absurdo; luego ni lo es en el foro"." (Laercio, VI, ii, § 35, p. 151) También Crates hacia el amor en público con su esposa Hiparquia (VI, vii, $\S 1$, p. 158).

5 Según Laercio, Diógenes de Sínope "incluso trató de comer carne cruda, pero no la pudo digerir" (VI, ii, § 9, p. 142); y según Plutarco, "Diógenes el Cínico apenas usaba fuego, de manera que dijo cuando se comió un pulpo crudo: "así, por vuestro bien me arriesgo"." (Sobre si es más útil el agua que el fuego, 2, § 956 b, t. IX, p. 243).

${ }^{6}$ El lector puede hallar interesantes consideraciones sobre el "bestiario" filosófico cínico en el capítulo "Emblemas del perro", incluido en Cinismos. Retrato de los filósofos llamados perros, de Michel Onfray (2002: 35-43).

7 Ya Antístenes "era apodado Aplocuón" (Laercio, VI, ii, § 8, p. 137), esto es, 'perro simple, manso o genuino'. En lo que respecta a Diógenes de Sínope, son múltiples los testimonios que indican que era conocido como "el Perro". Véase, entre otros, Laercio VI, ii, pp. 142, 143, 145, 147 y 149. Sobre la posibilidad de que los Hemikynes (medio perros) o Kinokephaloi (cabezas de perro) de los que hablaron Hesíodo, Estrabón o Ctesias se hallen en el origen del nombre y el imaginario caninos de los cínicos, véase White (1991:50) y Romm (2000:177). Recuérdese que también Marco Polo, John Mandeville y Cristóbal Colón hablaron de hombres con cabeza de perro. 
doméstico, sino, antes bien, un perro salvaje, acostumbrado a una dura vida de supervivencia, libertad y desvergüenza, en el seno de la polis. Es en este sentido, claro está, que debe entenderse el título de este artículo.

La desconfianza respecto de la filosofía especulativa y la escritura, entendidas como productos degenerados de la civilización, les llevó a expresar su forma de vida filosófica con anécdotas, apotegmas y respuestas ingeniosas. El frondoso anecdotario cínico se nutre, fundamentalmente, del libro VI de las Vidas de los filósofos más ilustres, de Diógenes Laercio, y, en menor medida, de los opúsculos de Luciano de Samósata, las Epístolas pseudodiogénicas y algunas referencias en las obras de autores como Séneca, Arriano, Epictecto, Juliano o en libros como la enciclopedia bizantina del siglo X, conocida como la Suda. ${ }^{8}$ El carácter no escritural de estos happenings filosóficos dificulta la tarea de establecer una doctrina cínica. De lo que no cabe duda es de que todas estas anécdotas remiten a prácticas filosóficas o, como diría Pierre Hadot, "ejercicios espirituales", que buscan violentar a los hombres, que, engañados por las sirenas de la civilización, viven sumidos en la inautenticidad, la servidumbre y la infelicidad, con la esperanza de hacerlos regresar a una vida natural y radicalmente libre. ${ }^{9}$

A pesar del carácter provocador e, incluso, violento de los filósofos cínicos, su radical autonomía, ascetismo y valentía a la hora de criticar los vicios de sus contemporáneos les valió ser admirados, no sólo por los grecolatinos, sino también por los primeros pensadores cristianos. Ya en el siglo II d.C., Orígenes comparará la pobreza de Jesucristo con la de Diógenes de Sinope. ${ }^{10}$ Dos siglos más tarde, San Juan Crisóstomo relacionará el ascetismo cínico con el monaquismo cristiano, en Contra los impugnadores de la vida monástica ("Discurso II", § 4 y 5, pp. 417420), mientras que Asterio, obispo de Amasea, y San Basilio de Cesarea proclamarán en diversas ocasiones su admiración por Diógenes de Sínope (Martín García, 2008: II, 1111). ${ }^{11}$ A pesar de todo, las relaciones entre los filósofos cínicos y los apologetas cristianos no fueron fáciles, puesto que entre ambos se estableció una violenta "competencia de atracción de seguidores" (II, p. 933). Valga como ejemplo la disputa que mantuvieron en el siglo II d.C. el filósofo cínico Crescencio

${ }^{8}$ El lector puede hallar una exhaustiva antología del rico anecdotario cínico en la antología de testimonios Los filósofos cínicos y la literatura moral serioburlesca, de José A. Martín García. En dicha obra pueden leerse las Epístolas pseudodiogénicas (pp. 391-429).

9 Sobre el concepto de "ejercicio espiritual" en las filosofías helenísticas, véase los trabajos de Onfray (2002 y 2008:131-142), Nussbaum (2003) y Hadot (2006).

10 "Pero también Diógenes habitaba en un tonel por su exagerada parquedad, porque Diógenes no hubiera vivido mal en casa de ningún hombre que tuviera juicio, aunque fuera modesto" (Contra Celso, II, 41, en Los filósofos cínicos, I, p. 352, § 498).

${ }^{11}$ Estas semejanzas explicarían el curioso caso de Máximo Herón de Alejandría, quien, en el siglo IV d.C., trataría de ser cristiano y cínico al mismo tiempo. Véase al respecto Los filósofos cínicos, pp. 1110-1123. 
o Crescente y el apologeta cristiano Justino, quien acabó sufriendo martirio, durante el reinado de Marco Aurelio, a causa de su fe cristiana, y por instigación de su adversario filosófico. ${ }^{12}$ Con todo, las comparaciones entre el cinismo y el cristianismo perdurarán durante toda la Edad Media, para intensificarse, luego, durante el Renacimiento. Tanto es así que todavía en el siglo XVIII, la entrada "Cínicos" de la Enciclopedia de Diderot y D’Alembert retomaba, con ironía, este motivo, ${ }^{13} \mathrm{e}$, incluso, en nuestros días, algunos historiadores contemporáneos consideran que "el Jesús histórico" fue "un predicador cínico judío" (Kruek, 2000: 300; Downing, 1993, pp. 281-314). Sin embargo, lo que aquí nos interesa es notar que dichas concomitancias fueron las que permitieron que el recuerdo del cinismo perdurase durante la Edad Media.

La postura que los hombres del medioevo mantuvieron respecto de los cínicos fue la de San Agustín, quien, en La ciudad de Dios, dice que admira su estilo de vida, ascético y digno (La ciudad de Dios, § 19,397), si bien les afea su impudicia $(\S 14,20,43)$. Fueron dos las fuentes principales de la filosofía cínica durante este período. En primer lugar, los autores latinos, ya fuesen paganos (Cicerón, Valerio Máximo, Séneca, Macrobio, Aulo Gelio) o cristianos (San Jerónimo, San Agustín, Tertuliano, Sidonio Apolinar). En segundo lugar, los autores árabes, fundamentalmente, Abu 'l-Wafa' al-Mubashshir ibn Fatik, cuyo importante Mukhtar al-hikam wa-mahasin al-kalim, del siglo XI, contenía numerosas anécdotas y dichos de Diógenes de Sínope, que habían sido olvidados en Occidente. ${ }^{14}$ Dicha obra, que fue traducida al castellano, en el marco de la corte de Alfonso X, con el título de Bocados de oro, adquirió proyección europea, a finales del XIII, tras ser retraducida al latín con el título Liber Philosophorum Moralium Antiquorum, que también se conocería como Dicta et Opiniones Philosophorum (Matton 2000: 315-316). Los testimonios cínicos procedentes de las fuentes latinas y árabes se difundieron por toda la Edad Media a través de numerosas obras misceláneas de corte "enciclopédico", como, por ejemplo, antologías de aforismos o biografías de filósofos. Sin embargo, también unas cuantas obras propiamente literarias contribuyeron a difundir esta versión "domesticada" del cinismo. ${ }^{15}$

\footnotetext{
12 Para una exposición general de esta disputa, véase Los filósofos cínicos, II, pp. 931935.

13 "Poned un bastón en la mano de algunos cenobitas del monte Atos, que tienen ya la ignorancia, la indecencia, la pobreza, la barba, el hábito grosero, la alforja y las sandalias de Antístenes. Suponedles, a continuación, la elevación del alma, una pasión violenta por la virtud y un odio vigoroso hacia el vicio. El resultado será una secta de Cínicos." La traducción es nuestra.

${ }^{14}$ Sobre la figura de Diógenes de Sínope en las obras árabes medievales, véase Gutas (1993:475-518).

${ }^{15}$ Tal será el caso, por ejemplo, del Policraticus de Juan de Salisbury, donde se ensalza el ascetismo de Diógenes; de la Divina comedia de Dante, donde se ubica a este último en el
} 
Por otra parte, la orden franciscana, que no sólo fue fundamental en la "conquista espiritual" del Nuevo Mundo, sino también en la configuración del mito del buen salvaje, mantuvo una especial afinidad con los filósofos cínicos. Recordemos, con Phelan, que "la génesis del buen salvaje puede encontrarse en la tradicional imagen franciscana de la naturaleza humana, desarrollada alrededor del culto a la pobreza apostólica, a la simplicidad primitiva y al misticismo joaquinita" (1976: 100). Tanto es así, que el autor de El reino milenario de los franciscanos en el Nuevo Mundo llegará a afirmar que la Historia eclesiástica indiana de Jerónimo de Mendieta, supone "una transición entre Francisco de Asís y Rousseau, entre el siglo XIII y la Ilustración” (101). Por otra parte, la afinidad entre la filosofía cínica y la orden seráfica no pasó por alto a autores como Piero Valeriano o Justo Lipsio, quienes, en el libro V de su Hyeroglyphica (1556) y en el libro III de su Manuductionis ad Stoicam Philosophiam (1604), respectivamente, compararán a los cínicos con los franciscanos (Matton 2000: 333). Ya en nuestros días, Kinney considerará que el estilo que cultivaban los predicadores callejeros franciscanos recuerda "la estudiada imprudencia de los cínicos" (2000: 401). Ciertamente, muchas de las anécdotas tan asociadas a San Francisco, al que Santa Clara dio en llamar "juglar de Dios", apelativo que él mismo aplicó luego a sus seguidores, ${ }^{16}$ nos recuerdan enormemente a las chreiai que Antístenes, Diógenes o Crates protagonizaron. Ya Horacio había hecho decir a un filósofo cínico: "[soy] mi propio bufón" (Epístolas I 17, 13); ya Diógenes de Sínope había llamado "hermanos" a los perros (Laercio, VI, ii, $\S 42$, p. 153) y se había paseado "por la nieve con los pies desnudos" (VI, ii, $\S 9$, p. 142); y ya Crates había arrojado sus riquezas al mar antes de seguir a Diógenes (VI, v, $\S 2$, p. 155). Coincidimos, pues, con Kinney [2000:410], en que este tipo de concordancias contribuyeron a la formación de un "cinismo cristiano", de corte utópico, que se nos habrá de revelar fundamental a la hora de analizar los presupuestos filosóficos sobre los que se basó la idealización del indio americano.

A pesar de la relativa importancia de la filosofía cínica en el imaginario medieval, no será hasta la época renacentista cuando ésta se difunda más amplia y fielmente. La fuente principal de este "renacimiento cínico" serán las Vidas de los filósofos más ilustres, de Diógenes Laercio, que fueron traducidas al latín, en 1433, por Ambrosius Traversarius. Precisamente, el libro VI de dicha obra está

Limbo, junto a los filósofos más importantes del mundo grecolatino (Infierno, 4, 130-144); de Los triunfos de Petrarca, donde se lo alaba, nuevamente, sin dejar de criticar, por eso, su anaideia o "desvergüenza", al más puro estilo agustiniano; o de los De Casibus Virorum Illustrium, de Boccaccio, donde se lo equipara a San Juan Bautista.

${ }^{16}$ Véanse las estimulantes reflexiones que G. K. Chesterton hace al respecto en el capítulo 5, titulado "Juglares de Dios", de su obra San Francisco de Asís. Nótese, a su vez, las semejanzas entre la vida de Santa Clara y la de la filósofa cínica Hiparquia, compañera de Crates (Laercio, VI, vii). 
íntegramente dedicado a la filosofía cínica, que es presentada como una de las diez grandes escuelas filosóficas. Otras fuentes importantes del cinismo, recuperadas también durante la época renacentista, fueron las Moralia u Obras morales y de costumbres, de Plutarco, que empezaron a ser traducidas al latín a finales del siglo XIV, si bien no se imprimieron hasta 1509; los opúsculos de Luciano de Samósata, algunos de los cuales fueron traducidos al latín por Erasmo y Tomás Moro; o las Epistolas apócrifas de Diógenes de Sínope y de Crates, que se tradujeron al latín en el siglo XV.

Gracias a estas obras, una renovada y más profunda visión del cinismo se difundió por toda Europa. Así, en el famoso adagio de Erasmo titulado "Los silenos de Alcibíades", dos de los cuatro filósofos que se proponen como paradigma del sileno -Sócrates, Antístenes, Diógenes y Epicteto- serán cínicos. ${ }^{17}$ Este hecho no es anecdótico, ya que unas pocas líneas más abajo Erasmo llegará a preguntarse: “¿No fue Cristo un maravilloso Sileno?" (Los adagios del poder, p. 112) Unas páginas más adelante, Erasmo volverá a equiparar a los cínicos con Cristo y los santos, al afirmar que Cristo rechaza las riquezas que "hacían reír a Demócrito", "llorar a Heráclito" y "que como frívolas despreciaba Diógenes, que por onerosas rechazaba Crates, y de las cuales huyeron siempre los santos como de la peste?" (p. 135) ${ }^{18}$ Por si esto no fuese suficiente, en un texto tan importante como el Paraclesis-Methodus, que sirvió de prefacio a los dos tomos de su primera edición del Nuevo testamento (1516), y en el que Erasmo cifró la esencia de su philosophia Christi, vuelve a relacionarse directamente el cristianismo con la filosofía cínica. Para empezar, Erasmo afirmará que "la filosofía de Cristo, que él mismo llama renacimiento, ¿no es, en efecto, otra cosa que la restauración de la naturaleza, que fue creada buena?" (Éloge de la folie. Adages..., p. 601); por esta razón, el autor considera que no es extraño que se encuentren en los libros paganos muchos puntos que concuerden con la doctrina cristiana, y que puede llegar a afirmarse que "una buena parte de nuestra doctrina fue practicada por más de uno, sobre todo por Sócrates, Diógenes y Epicteto" (p. 601). Pero Erasmo no se limita a presentar a Diógenes como uno de los precursores de Cristo, sino que llegará a afirmar que los actos naturales no son obscenos; punto en el que no está siguiendo tanto el tópico latino (naturalia non sunt turpia), como el hipernaturalismo cínico, tal y como se entiende por el

17 "De este modo fue Sileno Antístenes, que con su báculo, su zurrón y su capa, aventajaba en fortuna a los más grandes monarcas. De este modo fue Sileno Diógenes, al que la gente trataba como a un perro. Sin embargo, algo de divino hubo de percibir en ese perro Alejandro (quien parecía ser el corifeo y el "alfa" de todos los príncipes) cuando, admirado de su grandeza de ánimo, dijo que de no haber sido Alejandro habría preferido ser Diógenes (¡cuando precisamente por ser Alejandro debería haber preferido el espíritu de Diógenes!)”. (Erasmo, Adagios del poder y de la guerra, p. 112)

${ }^{18}$ Erasmo llegó a dedicar dos adagios enteros a los cínicos: el número 1234, titulado "Canina facundia" y el número 2070, titulado "Ad Cynosarges". 
contexto de la cita, así como por el desarrollo que realizará de este tema en su Banquete religioso. ${ }^{19}$

Asimismo, en su Enchiridion (1503), que fue tan importante para los misioneros americanos, Erasmo hará referencia a cómo Crates arrojó sus riquezas al mar, antes de seguir a Diógenes (Éloge de la folie. Adages..., p. 563); ${ }^{20}$ pasaje al que volverá a hacer referencia en su Plan de estudios, de 1511 (p. 453). En La temprana educación liberal de los niños (1528), presentará a Antístenes como modelo de educación de los niños (p. 489); hará referencia a la admiración que Alejandro profesaba por Diógenes -"Si no fuese Alejandro, querría ser Diógenes", que recoge de Laercio (VI, ii, § 8, p. 141)-; representará al cínico Crates en lo alto de un monte reprochando a los tebanos su codicia (Éloge de la folie. Adages..., p. 487); y hablará del "Diario de Crates" (p. 500), una especie de diario satírico dirigido a un público popular, en el que el discípulo de Diógenes criticaba la avaricia de sus contemporáneos (Laercio VI, v, § 1, p. 155). No olvidemos lo importante que fueron ambas obras para la educación de uno de los principales reformuladores del mito del buen salvaje, esto es, Michel de Montaigne, cuyo padre las adoptó como guía para dirigir su particular educación. También en sus Coloquios, Erasmo hará numerosas referencias al cinismo. Así, en El epicúreo, Espudeo afirmará que "los cristianos se parecen, sobre todo, a los cínicos" (Éloge de la folie. Adages..., p. 374) y elogiará su pobreza voluntaria en otros diálogos como Ptokhologia o "Discurso del pordiosero" y Ptokhoplousioi o "Los pordioseros ricos". Incluso en su correspondencia Erasmo tendrá presentes a los cínicos como un modelo a seguir. Así, en la carta que envió a Helius Eobanus Hessus el 11 de agosto de 1531, tras confesarse agobiado por los problemas económicos y de intendencia, nuestro autor llegará a afirmar: "nunca me pareció tan sabio el comportamiento de Diógenes cuando se refugiaba en un tonel" (Éloge de la folie. Adages..., p. 1187).

Los cínicos no sólo representaban, para Erasmo, un modelo de sencillez e independencia cuasi divinas, sino también una importante fuente de inspiración para la crítica del ritualismo religioso, el espiritualismo antiintelectualista y el proyecto de reducción al mínimo del núcleo doctrinal, que caracterizaban la devotio moderna que él propugnaba. Ciertamente, el "vago teísmo natural" y su "desconfianza burlona hacia las religiones positivas y convencionales, con sus muchos dioses, y sus ceremonias" (García Gual, 1996: 41) nos recuerdan inevitablemente a la actitud

19 Notemos que Juliano realizó exactamente la misma operación al afirmar que los cínicos, que en estos fragmentos hacen las veces de cristianos, tuvieron precursores entre los "bárbaros": "Estoy convencido de que tuvo algunos [practicantes] ya antes de que él [el cinismo] existiera, y no sólo entre los griegos, sino también entre los bárbaros, porque es la filosofía que parece ser, en cierto modo, universal, muy natural y que no requiere ninguna especial dedicación intelectual." (Juliano, Discursos IX [VI] 8, p. 187 b-c, en Los filósofos cínicos, I, p. 142, § 64) Véase también Juliano, Oración 6, 187c-d.

${ }^{20}$ Véase al respecto Bataillon (1966:197). 
que Erasmo y sus discípulos mantuvieron hacia el ritualismo y el dogmatismo que caracterizaban la iglesia católica del momento.

Una vez establecida la importancia, tan poco estudiada, del cinismo en Erasmo, bastará recordar la fuerte impronta erasmista que presentan la mayoría de los autores que contribuyeron a la reformulación moderna del mito del buen salvaje. Ciertamente, se ve una fuerte influencia erasmista y, por lo tanto, cínica, tras muchos de los argumentos, motivos e imágenes que se congregan en la "constelación mítica" ${ }^{21}$ del buen salvaje, que invocan autores españoles, como Juan de Zumárraga, Vasco de Quiroga, Bartolomé de Las Casas o Fernán Pérez de Oliva, y extranjeros, como Montaigne, La Mothe Le Vayer o Cyrano de Bergerac. Recordemos, para empezar, el capítulo "Erasmo y el Nuevo Mundo", incluido en Erasmo y España, de Marcel Bataillon, donde se afirma que muchos muchos misioneros estaban influidos directamente por el erasmismo (1966: 819-822) ${ }^{22}$ Otra prueba de la importancia que tuvo este "cinismo erasmista" en los predicadores renacentistas es la obra del dominico fray Luis de Granada, quien le otorgará un lugar fundamental a los cínicos, en general, y a Diógenes de Sínope, en particular, tanto en su antología de máximas para uso de predicadores, titulada Collectanea Moralis Philosophiae (1571), como en sus propios sermones (Matton 2000: 330). ${ }^{23}$

Pero Erasmo, y con él Europa, no sólo conoció el imaginario cínico a través de las recientemente traducidas Vidas de los filósofos más ilustres, de Diógenes Laercio, sino también a través de los opúsculos de Luciano de Samósata. Lo cierto es que Erasmo y Tomás Moro no sólo tradujeron -a veces juntos- muchas de las obras de Luciano, entre ellas el diálogo titulado El cínico, sino que, además, tanto el Elogio de la locura como la Utopía acusan una fuerte impronta lucianesca y, por lo tanto, cínica. No importa demasiado si consideramos a Luciano un cínico (Relihan, 2000: 349) o un escéptico, ya que es cierto que Luciano lanzó algunas críticas

21 Para una tematización del concepto de "constelación mítica", véase Mitologías políticas, de Raoul Girardet.

22 Maravall, si bien acepta que algunos misioneros, como Las Casas, Motolinía, Mendieta o Torquemada, tenían una sensibilidad humanística (1982: 83), considera que no hay pruebas al respecto (89). Le responden satisfactoriamente Martín Hernández, quien aportará, entre otras muchas pruebas, las numerosas alusiones que Juan de Zumárraga realizará al Enchiridion y a la Paraclesis de Erasmo en su Doctrina breve, de 1547 (1992:45-84). Véase también Green [1969: 78], Phelan [1972:72], Broda [1975], Lafaye [1984: 156-160], Liss [1986: 164-165], Martín Hernández (1986:55-80) o Duch [1992: 212].

${ }^{23}$ No debemos pensar, sin embargo, que el cinismo fue aceptado sin problemas durante el Renacimiento. Tal es el caso, por ejemplo, de Pico della Mirandola, quien, a pesar de considerar, en su Examen Vanitatis (1520), que el cinismo y el cristianismo comparten numerosos aspectos, concluye que la felicidad perfecta no puede pasar por vivir como un perro, sino, antes bien, por vivir como Cristo (Matton, 2000: 335). 
contra la escuela cínica en opúsculos como Los fugitivos o El cínico (García Gual, 1996: 81). Lo que realmente nos interesa saber aquí de Luciano es que recogió, amplificó y difundió ideas y géneros literarios específicamente cínicos, como es el caso de la anécdota o chreiai, que tan magistralmente practicó Diógenes el Perro; la mezcla paródica de géneros literarios cómicos y serios, o spoudaigéloion ("seriocómico") inaugurada por Crates; la diatriba, que cultivaron Menipo, Bión y Varrón, quien fue considerado como "un Diógenes latino"; o ese particular desarrollo de la diatriba que fue la sátira menipea, que fue tan importante en toda la literatura española aurisecular. ${ }^{24}$

Erasmo acusará la influencia del cinismo literario de Luciano en el Elogio de la locura (1511). Dicha influencia no sólo se evidencia en su antiintelectualismo, su desvergüenza y su hipernaturalismo, sino también en la mezcla paródica de diversos géneros literarios. Baste recordar, entre los cientos de ejemplos posibles, el célebre capítulo 48, donde se describen las risas de los dioses que observan, desde el Olimpo, la estulticia de los mortales, y que nos remite directamente a las sarcásticas observaciones que Menipo y Caronte realizan desde el cielo en el Icaromenipo y el Caronte de Luciano de Samósata, quien, a su vez, continuaba la tradición cínica de la sátira menipea.

Como dijimos, Tomás Moro compartía con Erasmo la pasión por Luciano y, como era de esperar, también la Utopía acusa una fuerte impronta cínica. Baste apuntar la subversión del significado convencional del oro (los cínicos eran conocidos como "los falsificadores de moneda"), la presencia de pasajes que constituyen auténticas diatribas cínicas, las burlas lucianescas y, sobre todo, las referencias a toda una tradición cínica de "utopías" satíricas, que se remonta a la Politeia de Diógenes de Sínope. En dicha obra, que fue la particular respuesta del cinismo contra la República de Platón, Diógenes imagina una república cínica ideal en la que debería practicarse la frugalidad, la franqueza, ${ }^{25}$ el amor libre y la

${ }^{24}$ Sobre la importancia de Luciano en la literatura española de los siglos XVI a XVIII, véase Vives Coll (1959). Sobre el género de la sátira menipea en el mundo clásico, véase Relihan (1993). También puede encontrarse un interesante análisis de la pervivencia de la sátira menipea en la literatura española, a través de las teorías que Bajtín expuso en Problemas de la poética de Dostoievski, en Jiménez León (2000:311-337). Sobre las diatribas cínicas, véase Martín García (2008:291-295).

25 "Preguntado qué es lo mejor en los hombres, respondió: "La libertad en el decir"“، (Diógenes Laercio, VI, ii, § 34, p. 151) También Juliano elogia esa parresía o "libertad en el decir", que también se ha traducido como "franqueza": "[Quien quiera ejercer el cinismo debe], en primer lugar, hacer uso de la franqueza de expresión, cuando haya demostrado que se ha hecho merecedor de ella, como en mi opinión lo fueron Crates y Diógenes." (Juliano, Discursos IX [VI] 18, p. 200 d-20, p. 203 c en Los filósofos cínicos, I, p. 300, § 258) 
antropofagia. ${ }^{26}$ También la Utopía acusa la influencia del género cínico de la poesía paródica o spoudaigéloin, cuyo principal representante fue Crates. No en vano, en varios de los poemas citados por Laercio, Crates imagina ciudades e islas imaginarias: "Es noble la ciudad Zurrón llamada, / fastuosa, aunque mugrienta, / bella, amena, fecunda, y nada tiene." (VI, vi, § 1, p. 154) "Que él tenía por patria / el propio menosprecio y la pobreza, / a quienes la fortuna no consume"; (VI, v, § 6, p. 156); "Que de Diógenes era ciudadano, / a quien nunca la envidia lazos puso." (VI, v, § 6, p. 157). Coincidimos, pues, con Kinney, quien afirma que "queda mucho por decir de Utopía como invención cínica" (2000: 420, n. 64).

Una vez establecida la impronta cínica de la Utopía, cabe recordar la influencia que dicha obra tuvo en algunos de los principales enunciadores del mito del buen salvaje en América. Según Maravall, "el siglo XVI fue una de las épocas de mayor carga utópica de la historia moderna de Europa" (1982:112). Asimismo, sabemos que Las Casas estuvo fuertemente influido por la Utopía de Tomás Moro (Ordiz, 1988:5) y Almoina [1951:40-50] y Maravall (1982:79) nos informan de que el primer obispo de México, fray Juan de Zumárraga, poseía un ejemplar de la Utopía de Tomás Moro, cuyas anotaciones al margen indica que compartía muchos aspectos de su ideología y sensibilidad humanísticas. ${ }^{27}$ En general, la mayor parte de los misioneros compartían con los humanistas, en general, y con Tomás Moro, en particular, la sensación de que Europa había fracasado espiritualmente y que era necesario probar un nuevo renacimiento -religioso o cultural- en América (Borges, 1987: 5 y Duch, 1992:216). Como hemos visto, esta intuición, fundamental en la conformación del mito del buen salvaje, cuando no provenía directamente de la filosofía cínica, armonizaba por lo menos con buena parte de su imaginario.

\section{Motivos cínicos en el mito del buen salvaje}

El mito del buen salvaje comparte con la filosofía cínica el hecho de poder secuenciarse en dos momentos filosóficos muy semejantes. El primero, de corte destructivo, consistiría en una crítica radical de la cultura o civilización, que se concebiría como un estado de degradación que no acepta ningún tipo de mejora, ya que sus deficiencias no son circunstanciales, sino consustanciales. El segundo momento, de corte constructivo, propondría un retorno a un mítico e impreciso estado o vida natural, rayano en la vida primitiva (primitivismo) o, incluso, animal (teriofilia).

${ }^{26}$ Según Michel Onfray (2002:136-139), la apología de la antropofagia en el cinismo está íntimamente relacionada con el materialismo, de corte atomista.

${ }^{27}$ Sobre la influencia de la Utopía en América, véase también Abellán [1979: 373-389] y Zavala [1988: 1-8]. Sobre las utopías en general, véase el exhaustivo estudio de Manuel, Moreno y Fritzie [1984]. 
Uno de los primeros motivos del momento destructivo cínico es la crítica contra el debilitamiento corporal y espiritual que las comodidades y los excesos de la vida civilizada suponen. Según afirma Laercio, en Vidas de los filósofos más ilustres, Diógenes "solía clamar con frecuencia, diciendo que "los dioses han dado a los hombres una vida fácil; pero que ésta se oculta a los que van buscando dulzuras, ungüentos y cosas semejantes" (VI, ii, § 17, p. 144). ${ }^{28}$ Este tipo de críticas también serán constantes en buena parte del corpus cronístico, así como en buena parte de las obras de corte humanístico que trataron la cuestión americana. Tal es el caso, por ejemplo, de la magnífica descripción de la molicie y de la decadencia de los colonos españoles, en el siguiente fragmento de la Historia de los indios de la Nueva España, del fraile franciscano fray Toribio Benavente "Motolinía":

Ver con cuánta pesadumbre se levanta un español de su cama muelle, y muchas veces le echa de ella la claridad del sol, y luego se pone un monjilazo, porque no le toque el viento, y pide de vestir, como si no tuviese manos para lo tomar, y así le están vistiendo como a manco... (I, 14, p. 82)

También Montaigne afirmará, en "De los caníbales" (I, xxxi) y en "De los carruajes" (III, vi), sus dos ensayos más influyentes en la conformación del mito del buen salvaje, que los excesos de la civilización debilitan la salud física y moral de los hombres. En "De los caníbales", los europeos serán vistos como frutos cultivados "que hemos alterado con nuestras artes, desviándolos del orden común", con el objetivo de adaptarlas " al placer de nuestro gusto corrompido." (I, xxxi, t. I, p. 268); y en "De los coches", se presentará el contacto entre el mundo indígena y la degradada civilización europea como un "contagio":

Mucho me temo que hayamos apresurado mucho su decadencia y ruina por nuestro contagio, y que le hayamos vendido muy caras nuestras ideas y nuestras artes. (III, vi, t. III, p. 146)

Otro motivo fundamental del momento destructivo de la filosofía cínica, así como de la versión moderna del mito del buen salvaje, es la crítica a la codicia de dinero (philargyría) o de bienes materiales (aischrokérdeia). Coherentes con la opinión de Diógenes de Sínope, quien consideraba que "la pasión por el dinero es la metrópolis de todos los males" (Laercio, VI, ii, § 22, p. 146), Crates renunció a sus riquezas para dedicarse a la filosofía, tal y como la entendían los cínicos (VI, v, § 2, p. 155), y el esclavo Mónimo arrojó al aire las monedas de plata con las que negociaba, logrando, de este modo, la libertad, al pensar su amo que la "locura" lo había tornado inútil (VI, iii, $\S 1$, p. 154). Dicho motivo, cuatro siglos anterior al

${ }^{28}$ Véase al respecto Castany (2013:279-291). 
rechazo de las riquezas del cristianismo primitivo, ${ }^{29}$ que, según Pierre Hadot, tuvo fuertes influencias helenísticas (2003: 59-78 y 177-190), será un elemento fundamental del imaginario franciscano, que tanta importancia tuvo en la conformación del mito del buen salvaje. Lo cierto es que tanto en el corpus cronístico como en los textos humanistas europeos son constantes las diatribas contra la fiebre del oro que caracterizó la conquista y la colonización americana. Ya Colón habla de la codicia de los españoles en una anotación del 22 de diciembre de 1492:

Porque como fuesen tan francos los indios y los españoles tan codiciosos y desmedidos, que no les basta que por cabo de agujeta, aun por un pedazo de vidrio y de escudilla y por otras cosas de no nada les daban los indios cuanto querían, pero, aunque sin darles algo se los querrían todo haber y tomar (en Textos y documentos completos, 93).

A partir de este momento, la crítica a la codicia de los españoles va ser una constante en todas las crónicas de indias. Coincidimos, pues, con Caro López (1998: 441-458), en que la crítica moralizadora de la conquista de América se centraba, fundamentalmente, en el tema de la codicia, siendo el indiano el símbolo del hombre codicioso y depravado, en oposición al modelo del buen salvaje. Recordemos, con José Luis Abellán, que la idea de "buen salvaje" aparece formulada ya en la fábula "El villano del Danubio", incluida en el tercer capítulo del tercer libro de El reloj de príncipes (1529), de Antonio de Guevara. En dicho pasaje, un bárbaro germánico afea la vida bárbara de los romanos, llegando a oponer la civilización como fuente de corrupción y el estado de naturaleza como lugar de inocencia y de felicidad. (1979: t. II, p. 79 y p. 409) ${ }^{30}$ Por su parte, Alfonso de Valdés, en su Diálogo de Mercurio y Carón, de fuerte impronta erasmista, lucianesca, menipea y, por lo tanto, cínica, hace referencia a la degradación moral que los indígenas han sufrido por culpa del mal ejemplo que ha supuesto para ellos la codicia de los españoles:

Fuime a un reino nuevamente por los cristianos conquistado, y diéronme de ellos mil quejas los nuevamente convertidos, diciendo que de ellos habían aprendido a hurtar, a robar, a pleitear y a trampear. (p. 87)

${ }^{29}$ Recuérdese el pasaje del joven rico en Marcos, 10, 21: “21 Jesús, fijando en él su mirada, le amó y le dijo: Una cosa te falta: anda, cuanto tienes véndelo y dáselo a los pobres y tendrás un tesoro en el cielo; luego, ven y sígueme".

${ }^{30}$ Sobre las fuentes clásicas de este tipo de diatribas puestas en boca de bárbaros, véase Romm [2000:163-181]. 
El mismo tipo de argumentos hallamos, en Menosprecio de corte y alabanza de aldea (1539), en cuyo capítulo XVII Antonio de Guevara citará a Diógenes de Sínope para criticar la codicia de los españoles, en general, y, según Caro López, de los españoles pasados a América, en particular; ${ }^{31} \mathrm{o}$ en Las cortes de la muerte (1557), de Luis Hurtado de Toledo y Miguel de Carvajal, fuertemente influida por Erasmo y Las Casas (Caro López, 1999:443 y Rodríguez Puértolas, 1961:655), donde se dice que los españoles han enseñado a los indios a robar y a pleitear, cuando ellos despreciaban el oro, por no darles, como tampoco lo hacían los cínicos, el mismo valor convencional que le dan los hombres llamados "civilizados":
Una cosa que les damos [el oro]
de buena gana, o en paz,
porque allá no lo estimamos
en tanto, ni reputamos
por causar males asaz.
Que aunque la India es tenida
por simple, cierto no yerra
en despreciarlo, y lo olvida;
que al fin es tierra cocida
en las venas de la tierra. (p. 32)

Asimismo, en su Historia general y natural de las indias, Gonzalo Fernández de Oviedo denostará "la codicia de los hombres insaciable" (III, vi) y, en su Brevísima, Bartolomé de Las Casas considera que la causa de la violencia ejercida contra los indios es "la insaciable cudicia y ambición que han tenido, que ha sido la mayor que en el mundo ser pudo" (p. 13).

Como era de esperar, este tipo de críticas tendrá una especial importancia en autores franciscanos, como Motolinía, Mendieta o Sahagún, para los que la pobreza era un valor espiritual supremo, hecho que, como vimos, les llevó a interesarse, en diversas ocasiones, por los filósofos cínicos. Motolinía coincidirá con Las Casas en que la codicia es la fuente de todos los males sucedidos en América -"si alguno preguntase qué ha sido la causa de tantos males, yo diría que la codicia" (I, 3, p. 32)- y llegará a afirmar que "los españoles seglares" han sido "tiranos y crueles"

31 “Once años continuos estuvo el filósofo Diógenes en la casa y corte de Dionisio, el cual, como dejase a Dionisio y a su casa y se tornase a Grecia y un día estuviese lavando unas berzas, díjole otro filósofo por le motejar y aun lastimar: "Si tú no dejaras la corte de Dionisio, no lavaras berzas." Al cual respondió Diógenes: "Y aun si tú te contentases con berzas, no estarías en la corte de Dionisio"." (Antonio de Guevara, Menosprecio de corte, p. 140) 
con los indios porque "no miran más de a sus intereses y codicia que los ciega, deseándolos tener por esclavos y de hacerse ricos con sus sudores y trabajo?" (III,2, p. 173).

En su Historia eclesiástica indiana, fray Jerónimo de Mendieta afirmará, con un humor que no deja de recordarnos las ingeniosas observaciones de Diógenes, que, "viendo [los indios] la prisa que se daban [los españoles] a recoger el oro y la plata y otras cosas de precio y estima que podían haber", pensaron que querían regresarse pronto a su país, "y así esperaban el día de su partida" (III, xviii, t. I, pp. 135-136). En otros lugares Mendieta será mucho más duro, llegando a afirmar que:

... [la codicia] ha devastado y exterminado la viña haciéndose adorar (como la bestia del Apocalipsis) por universal señora, por poner los hombres ciegos toda su felicidad y esperanza en el negro dinero, como si no hubiera Dios en quien esperar y confiar, no abriendo los ojos para ver los patentes ejemplos que tenemos de los que han enriquecido en Indias, que llegados a tener en dinero o posesiones hacienda de quinientos y ochocientos mil ducados, y dende arriba, han bajado y venido a empobrecer, de suerte que unos murieron o mueren en cárceles y otros en hospitales, y para conocer la verdad del común refrán, que dinero de Indias es dinero de duendes, que volverse en carbón o humo no puede escapar (IV, xlvi, t. II, p. 125).

Finalmente, en su Historia general de las cosas de la Nueva España, Bernardino de Sahagún denostará la codicia de los españoles, cuya alegría al descubrir la existencia de oro entre los indígenas será descrita en los siguientes términos:

...se les puso risueña la cara, se alegraron mucho, estaban deleitándose. Como si fueran monos levantaban el oro, como que se sentaban en ademán de gusto, como que se les renovaba y se les iluminaba el corazón. Como que cierto es que eso anhelan con gran sed, se les ensancha el cuerpo por eso, tienen hambre furiosa de eso. Como unos puercos hambrientos ansían el oro (XII, xvii).

Montaigne retomará dicho motivo desde su habitual, aunque poco estudiado, enfoque cínico en "De los caníbales", donde afirmará que el contacto de los caníbales con el mundo europeo les va a resultar "costoso", ya que "de este trato les vendrá la ruina, la cual supongo se habrá iniciado ya" (I, xxxi, t. I, p. 277). En "De los coches" seguirá la estela lascasiana al considerar que Europa, aprovechándose "de su ignorancia e inexperiencia", ha conducido a los indios "a la traición, a la lujuria, a la avaricia y a toda suerte de inhumanidad y crueldad, a ejemplo y modelo de nuestras costumbres" y que "jamás la ambición ni las enemistades públicas 
empujaron a los hombres unos contra otros a tan horribles hostilidades y a tan miserables calamidades." (III, vi, t. III, p. 148) 32 $^{32}$

Otro motivo característico del momento crítico del cinismo es el antiintelectalismo, como muestran las numerosas anécdotas, o chreía, que escenifican las chanzas de Diógenes contra las doctrinas de Platón, que aquél veía como epítome de la filosofía dogmática y especulativa. ${ }^{33}$ Ciertamente, el cinismo concuerda perfectamente con el humanismo, en general, y el erasmismo, en particular, en su rechazo de los enkyklia mathémata, o conocimientos meramente teóricos o científicos, en aras de la práctica de la ética, que para ellos constituía el verdadero núcleo de la sabiduría (García Gual, 1996: 39). Es en este sentido en el que el estoico del siglo II a.C., Apolodoro de Seleucis, habría descrito el cinismo como "un atajo para la virtud" (Laercio VI, ix, § 3, p. 159). También Petrarca, Erasmo, Moro y Montaigne rechazarán el frío intelectualismo del escolasticismo pseudo-aristotélico y apostarán por una vivencia más práctica de la filosofía y la religión. Así, en De mi ignorancia y de la de muchos otros, Petrarca rechazará la erudición y la especulación filosófico-teológica, por considerar que impiden el verdadero objetivo de la cultura, que es el estímulo de la virtud y la bonhomía: "a las letras me he dedicado con moderación y con el único objetivo de llegar a ser bueno" (p. 51). La misma actitud mostrará Erasmo en su Coloquio de los religiosos o Convivium religiosum, donde llega a afirmar:

Más lamentaría faltarme un libro de Cicerón o Plutarco que todo cuanto escribieron Escoto y sus pares, no porque los condene sin remisión, sino porque siento que con la lectura de los unos me vuelvo mejor, en tanto los otros me dejan más frío para la auténtica virtud y más querencioso para las disputas. (1947, p. 110)

${ }^{32}$ Otra fuente importante de este ensayo son las ingeniosas críticas que el rey de los etíopes realizó de los regalos que los embajadores persas le ofrecieron en el libro III, $\S 17$ 24 de la Historia de Herodoto. Sobre las conexiones entre este tipo de fuentes y la filosofía cínica, véase Romm (2000).

${ }^{33}$ Dicho intelectualismo se halla cifrado en aquella anécdota que muestra a Diógenes buscando a un hombre en el ágora con un farol encendido en pleno día, y que no deja de ser una burla contra la idea platónica de "humanidad" (Diógenes Laercio VI, ii, § 15, p. 144). También es célebre la anécdota según la cual Diógenes habría lanzado una gallina desplumada al centro del corro en el que Platón estaba definiendo al hombre como "ser bípedo implume" (VI, ii, § 14, p. 143); aquélla según la cual, "disputando Platón acerca de las ideas, y usando de las voces mesalidad y vaseidad, [Diógenes] dijo: "Yo, oh Platón, veo la mesa y el vaso; pero no la mesalidad ni la vaseidad"." (VI, ii, § 24, p. 147); o aquélla según la cual habría comenzado a caminar alrededor de Zenón mientras éste exponía sus argumentos contra la existencia del movimiento (Sexto Empírico, Esbozos pirrónicos, III x, $\S 66$, p. 256). 
Bartolomé de las Casas se halla, precisamente, en esta línea cuando afirma, en su opúsculo "Contra los perseguidores y calumniadores de los pueblos del Nuevo Mundo descubiertos en el océano (1550-1551)": "Mandemos a paseo en esto a Aristóteles, pues de Cristo, que es verdad eterna, tenemos el siguiente mandato: "Amarás a tu prójimo como a ti mismo"“ (Las Casas, 1999, p. 54).

Pero lo que más nos interesa aquí es el hecho de que este antiintelectualismo cínico, estrechamente conectado con el escepticismo antiguo, conformará, junto con las derivaciones místicas de la teología negativa o apofática -cristiana, judía o musulmana-, la doctrina de la "docta ignorancia", de Nicolás de Cusa (s. XIV), y el escepticismo pirrónico, de Erasmo y Montaigne, el argumentario del que surgirá, a comienzos del siglo XVI, el motivo de la "ignorancia sabia" de los indígenas. Desde esta perspectiva, el desconocimiento por parte de los indígenas de ciertos aspectos teológicos o técnicos será entendido como una ventaja respecto del frío intelectualismo y el arriesgado dogmatismo de los europeos "civilizados" en la vía hacia la felicidad y la salvación. Ciertamente, la idealización de la estulticia, conocida tradicionalmente como "morofilia", ha sido tradicionalmente relacionada con el escepticismo, grecolatino, judeocristiano o islámico. Sin embargo, el cinismo es una fuente fundamental para todos aquellos autores predispuestos a idealizar o, por lo menos, excusar la ignorancia que se le atribuía a los pueblos indígenas recién descubiertos. ${ }^{34}$

No es extraño, pues, que Antístenes llegase a proponer, provocativamente, a Ciro, rey persa, bárbaro desde la perspectiva griega, como modelo de virtud. Otra modalidad de "barbarie" que los filósofos cínicos elogiarán e, incluso, practicarán, es la de la esclavitud, que modularán siguiendo el motivo del doûlos árchon o "esclavo gobernante", que es vendido a un amo (en sentido social) que necesita un amo (en sentido moral). Este es el motivo principal de la desaparecida La venta de Diógenes o La almoneda de Diógenes, de Menipo, que cita Laercio en sus Vidas de los filósofos más ilustres (VI, ii, §6, p. 141), así como de la Subasta de vidas de Luciano de Samósata (II, 30-53), un autor al que Erasmo y Tomás Moro admiraron y tradujeron. ${ }^{35}$

${ }^{34}$ Sobre la idealización, no sólo escéptica, sino también cínica, de los indígenas en tanto que "ignorantes sabios", véase mi artículo "Asnos en el paraíso: La influencia de la filosofía escéptica en la construcción del mito moderno del buen salvaje" (en prensa). Sobre la apasionante cuestión de los viajeros protocínicos y cínicos y de las diatribas contra la civilización griega puestas en boca de los "bárbaros", véase "Cabezas de Perro y Nobles Salvajes: ¿Cinismo antes de los cínicos?” (Romm, 2000:163-181) y “El acento escita: Anacarsis y los cínicos" (Martin, 2000:182-207).

35 "Refiere Menipo en La almoneda de Diógenes que, habiendo sido hecho cautivo, como al venderlo le preguntasen qué sabía hacer, respondió: "Sé mandar a los hombres"." (Laercio, VI, ii, § 6, p. 141) También Plutarco incluye la anécdota en Si el vicio puede causar infelicidad (3, $\$ 499$ b, t. VII, p. 225), Aulo Gelio, en Noches áticas (II 18, 9-10) y 
No debemos, pues, subestimar la influencia que dicha tradición pudo tener, no sólo en autores como Erasmo o Moro, sino también en todos aquellos a los que éstos influyeron y que tuvieron que enfrentarse al tema de la barbarie y de la esclavitud, oficial u oficiosa, de los indígenas americanos. Ciertamente, el hecho de que algunos de los filósofos más admirados de la Antigüedad fuesen bárbaros o esclavos, ${ }^{36}$ y que'considerasen dicha condición como una oportunidad en su apuesta por un radical ascetismo corporal y espiritual, pudo contribuir a idealizar, junto a otras muchas tradiciones filosóficas y religiosas, al indígena americano. Tal sería el caso, por ejemplo, de los franciscanos Motolinía, Sahagún o Mendieta, quienes, a pesar de querer mejorar la suerte de los indígenas, vieron en su pobreza radical una vía ascética para la salvación. Evidentemente, estos autores no iban a citar directamente las fuentes cínicas, si bien, como vimos en la primera parte de este artículo, numerosos pensadores cristianos vieron en Diógenes y en sus seguidores un ejemplo admirable de ascetismo.

Otro motivo importante del momento crítico del cinismo es el de la subversión de todas las convenciones, actitud que se resume en el lema paracharáttein tò nómisma, esto es, "falsificar o reacuñar la moneda" (Diógenes laercio, VI, ii, 1 p. 139). Con su aspecto (cabellos largos, barba desarreglada, manto tosco y zurrón), con su desvergüenza (anaideia), con su franqueza (parresía), con su rechazo de la buena fama (adoxia) y de la moneda, convención de las convenciones, ${ }^{37}$ con sus chistes, insultos y acciones insolentes y extemporáneas (chreiai), con sus masturbaciones y copulaciones públicas (Diógenes de Sínope y Crates e Hiparquia, respectivamente), así como con su apología de la antropofagia, los cínicos buscaban violentar todas las convenciones sociales, con la esperanza de provocar en sus

Luciano, en Subasta de vidas (II, pp. 36-37). Véase también Diógenes Laercio: "Objetándole una vez el que no era hijo de dos libres, respondió: "Ni tampoco de dos palestritas o luchadores, y no obstante, soy palestrita."“ (VI, i, § 4, p. 135)

${ }^{36}$ Diógenes fue admirado hasta tal punto que se convirtió en un tópico equipararlo e, incluso, mostrarlo como un ser superior a Alejandro Magno: "Demetrio trae en sus Colombroños que el mismo día en que murió Alejandro en Babilonia, murió Diógenes en Corinto." (Laercio, VI, § 42, p. 153) "Recordaron que la muerte del rey Alejandro y la del cínico Diógenes ocurrieron el mismo día." (Plutarco, Charlas de sobremesa VIII, I, 1, § 717 c., t. IV, p. 342) Marco Aurelio, también emperador, afirmará que Alejandro, Gayo y Pompeyo no son nada en comparación con Diógenes, Heráclito y Sócrates, pues "éstos vieron cosas, sus causas, sus materias, y sus principios guías eran autosuficientes; pero aquéllos, ¡cuántas cosas ignoraban, de cuántas cosas eran esclavos!” (Meditaciones, VIII, $\S$ 3, p. 146) Es fundamental al respecto, el diálogo entre Diógenes y Alejandro que Luciano imagina en los Diálogos de los muertos (IV, xiii, pp. 181-184).

37 "Diógenes, en su propia Constitución política, legisla que las tabas sean materia [o moneda] legal" (Ateneo, IV 159 c, en Los filósofos cínicos, I, p. 273 § 190). 
interlocutores la asunción de su carácter artificial y alienante, que debía verse seguido por un regreso a una vida natural.

Es de sobras conocido que la antropofagia fue uno de los temas fundamentales en las discusiones acerca de si los indígenas debían ser considerados seres humanos. Lo cierto es que, a la hora de enfrentarse a esta cuestión, Las Casas o Montaigne no pudieron hallar más que en la filosofía cínica -y quizás también en la escéptica, con la que el cinismo mantuvo unas relaciones muy estrechas- una mirada exculpadora de la antropofagia. El principal antecedente son un tratado político, la Politeia, y una tragedia, el Tiestes, de Diógenes de Sínope. Aunque ambas obras se perdieron, conservamos algunos testimonios gracias a Diógenes Laercio, Filodemo de Gadara o Cleantes. Según Filodemo de Gadara, Diógenes defendía que los habitantes de la república cínica que imagina en su Politeia "se alimenten... de los que mueran... y disponen, no obstante, que no hay diferencia entre que sean enterrados o que queden sin sepultura..." (en Filodemo, Sobre los estoicos: Papiro Herculanense, $\mathrm{n}^{\mathrm{o}}$ 339, Col XI, 3, recogido en Los filósofos cínicos I, p. 273-276, § 191) Según Diógenes Laercio, en el Tiestes, tras rechazar ciertas convenciones funerarias, Diógenes de Sínope afirma que "no es mal alguno tomar cosas de los templos, comer de todos los animales, y aun carne humana, como constaba por costumbre de otras naciones" (Diógenes Laercio, VI, ii, § 38, p. 152).

Así, cuando Montaigne afirme, en "De los caníbales", que "es más bárbaro comerse a un hombre vivo que comérselo muerto; desgarrar por medio de suplicios y tormentos un cuerpo todavía lleno de vida", no está haciendo más que seguir a Diógenes de Sínope, quien afirmó, en otro contexto, pero con el mismo argumento, que "es mucho mejor topar con los cuervos que con los aduladores, que devoran a los hombres buenos cuando aún están vivos"." (Ateneo, VI 254 c, recogido en Los filósofos cínicos I, p. 316, § 347). Asimismo, al final de dicho ensayo, Montaigne nos informa de que los tres caníbales que visitaron Francia se sorprendieron de que, en dicho país, los pobres no se rebelasen contra los ricos:

...observaron que había entre nosotros muchas personas llenas y ahítas de toda suerte de comodidades y riquezas; que los otros mendigaban de hambre y miseria, y que les parecía también singular que los segundos pudieran soportar injusticia semejante y que no estrangularan a los primeros, o no pusieran fuego a sus casas.

Dicho fragmento, además de recordarnos al opúsculo de su bienamado Étienne de La Boétie, titulado Contra la servidumbre voluntaria -de clara impronta cínica, por cierto-, nos remite inevitablemente a Diógenes de Sínope, quien "admirábase de los esclavos, "que viendo la voracidad de sus amos nada hurtaban de la comida". (Laercio, VI, ii, § 5, p. 140).

El rechazo cínico de la civilización será tan radical que llega a prescindir, incluso, de la escritura, que en tantas ocasiones ha sido considerada la frontera que separa la civilización de la barbarie, la historia de la prehistoria. No es extraño, 
pues, que los filósofos cínicos, como dijimos más arriba, apenas escribiesen, pues preferían expresar sus ideas o, mejor dicho, su modo de vida, a través de anécdotas, máximas u ocurrencias. De este modo, los cínicos reaccionaban contra los excesos retóricos y especulativos de la filosofía "oficial" y apostaban por un pensamiento que fuese realmente un "atajo hacia la virtud", que se basase en la acción, prescindiendo de fárragos, disputas y abstracciones. Este aspecto del cinismo no sólo tendrá una gran influencia en la apuesta por la consuetudo y la claritas de los humanistas, así como en el interés por el género de las anécdotas o chreíai-no son otra cosa muchos de los Adagia o Apotegmas de Erasmo o de las facecias del Lazarillo-, sino que también permitió a muchos de los pensadores de tendencia humanista que se enfrentaron a la cuestión americana el obviar, justificar o, incluso, elogiar el hecho de que los indígenas no tuviesen escritura. Ciertamente, si un sabio como Diógenes de Sínope había podido prescindir de la escritura, su desconocimiento no podía ser considerado un obstáculo fundamental en la consideración del indígena como un ser capacitado para el conocimiento filosófico y la salvación espiritual.

Pasemos, a continuación, a ver qué motivos del momento constructivo del cinismo pudieron influir en la construcción del mito moderno del buen salvaje. De algún modo, el momento constructivo del cinismo es el reverso de su crítica de la civilización. Sus supuestas ventajas civilizatorias no serían más que un intento desesperado de contrarrestar el carácter desnaturalizado del hombre. ${ }^{38}$ Esto es, precisamente, lo que Plinio sugerirá al comienzo del libro VII de la Historia natural, donde afirma que la naturaleza es más una madrastra que una madre para el hombre, pues los animales llegan al mundo vestidos, mientras que el hombre llega desnudo, siendo la desnudez del hombre no sólo una cuestión física sino, sobre todo, espiritual. Así, frente a la decadencia de los españoles, los autores que contribuyeron a forjar el mito moderno del buen salvaje atribuirán a los indígenas una vida frugal y salutífera, como prueba el siguiente fragmento de la Historia de los indios de Motolinía:

[Los indios], criados desnudos, viven buenos y sanos, y bien dispuestos, recios, fuertes, alegres, ligeros y hábiles para cuanto de ellos quieren hacer. Y lo que más hace al caso es, que ya que han venido en conocimiento de Dios, tienen pocos impedimentos para seguir y guardar la vida y ley de Jesucristo. (I, 14, p. 82)

También en "De los caníbales", Montaigne comparará a los indígenas con los frutos silvestres, en los que "se guardan vigorosas y vivas las propiedades y virtudes naturales, que son las verdaderas y útiles" (I, xxxi, t. I, p. 268).

\footnotetext{
${ }^{38}$ Véase al respecto los capítulos titulados "La naturaleza como norma" y "Primitivismo cínico" en Lovejoy y Boas (1935:caps. III y IV).
} 
La crítica de la codicia de los europeos presupone, a su vez, la idealización del buen salvaje en tanto que ser generoso y desprendido. Así, en Las cortes de la muerte, el alma de los indios que es convocada en esa danza de la muerte menipea dirán:

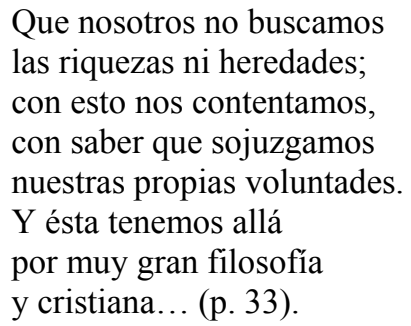

Es posible también intuir resonancias cínicas en algunos de los encendidos elogios de la pobreza de los indígenas que hallamos en franciscanos como Olmos, Motolinía, Mendieta, Sahagún y Mendieta o, incluso, en el propio Colón, que estuvo fuertemente influido por el franciscanismo (Milhou, 1983). Recordemos que la orden seráfica, que centraba su propuesta religiosa alrededor de la idea de "pobreza" o "desprendimiento" radical (Duch, 1992: 275), se identificó en diversas ocasiones con el duro ascetismo cínico. ${ }^{39}$ No es extraño, pues, que, en su idealización de la pobreza indígena, los franciscanos retomasen, aun sin ser conscientes de ello, ideas muy semejantes a las que motivaron aquella identificación. Tal sería el caso de Jerónimo de Mendieta, quien, en su Historia eclesiástica indiana, exaltará la pobreza de los indios en tanto que praeparatio evangelica apelando al Sermón de la Montaña:

Es cierto que no crió Dios, ni tiene en el mundo gente más pobre y contenta con la pobreza, que son los indios, ni más quitada de codicia y avaricia que (según

${ }^{39}$ Recordemos, entre tantas otras, la anécdota según la cual, "habiendo visto una vez que un muchacho bebía con las manos, sacó su colodra del zurrón y la arrojó, diciendo: "Un muchacho me gana en simplicidad y economía"." (Laercio, VI, ii, § 11, p. 142, también en Plutarco, Cómo percibir los propios progresos en la virtud, cap. 8, t. I p. 286 y en las Sátiras menipeas de Varrón, LVI, 9 y LXXI, 20). Más interesantes, quizás, son los testimonios de Estobeo, según el cual, "Diógenes decía que "la pobreza es la virtud autodidacta"“ (Estobeo, IV 32, 19, en Los filósofos cínicos, I, p. 311, § 312) y "que "la pobreza es una protección autodidacta de la filosofía, porque la pobreza fuerza con hechos a lo mismo que ella trata de convencer con palabras"." (Estobeo, IV 32, 11 en Los filósofos cínicos, I, p. 311, § 313) Nuevamente, Plutarco exclamará, en Sobre si el vicio puede causar infelicidad: "Pero ¿descenderás de una existencia brillante, de casa, mesa y dispendios al manto raído, la alforja y a mendigar el sustento diario? Esto es el principio de felicidad para Diógenes, el de la libertad y buena fama para Crates.” (cap. 3, § 499 c-d, t. VII, p. 226) 
San Pablo) es raíz de todos los males, ni más larga y liberal de lo poco que tienen. (IV, xxi, t. II, pp. 54-56)

Lo que no deja de recordarnos al siguiente testimonio de Plutarco:

Algunos hicieron, como Diógenes y Crates, del destierro de la patria y de la pérdida de riquezas viático para el ocio y para la filosofía. (Cómo sacar provecho de los enemigos, 2, § 87a, t. I, p. 309)

También en el siguiente fragmento del Libro perdido de Motolinía, que hemos podido recuperar gracias a una de las extensas citas que el oidor Alonso de Zorita realiza en su Breve y sumaria relación, descubrimos el motivo de la pobreza como oportunidad de salvación:

Éstos casi no tienen estorbo que los impida ir al cielo, de los muchos que a los españoles cercan y tienen sumidos, porque su vida de ellos se contenta con muy poco: su comida es muy pobre, e lo mesmo el vestir: duermen en una estera, y los más no la alcanzan: no se desvelan por adquirir riquezas, ni se matan por alcanzar estados ni dignidades: con su pobre manta se contentan, y en despertando están aparejados para orar [...] duermen en tierra, y cuando mucho tienen una estera vieja, y por cabecera una piedra o un madero. Sus casas son muy pequeñas, algunas de paja. Los santos buscaron esta vida, y la leemos para nuestro ejemplo, y nos maravillamos mucho. Nosotros en libros vivos lo leemos y lo vemos con nuestros ojos, y lo que vemos es más que lo que leemos e sabemos, que lo que pudiéramos creer. (pp. 130-131) ${ }^{40}$

Por otra parte, los cínicos consideraban que cualquiera podía emprender este camino ascético que llevase a la felicidad y a la sabiduría entendidas como una libertad radical. Pero no se trata sólo de que los esclavos, los desterrados, los bárbaros y las mujeres pudiesen llegar a ser sabios, sino de que, como acabamos de ver, esa condición desamparada ("no tienen estorbo", dice Motolinía) era, precisamente, la mejor vía para empezar a ser libres. ${ }^{41}$ Así, frente a Ginés de Sepúlveda, que compartía con Aristóteles la opinión de que los hombres nacen libres o esclavos por naturaleza (Cro, 1983:128), Las Casas, influido por Erasmo, quien, a su vez, estaba influido por los cínicos, considerará que nadie está condenado por nacimiento, sino que cualquiera puede salvarse.

40 Seguramente, el compilador de la Historia decidió omitirlo por considerarlo demasiado radical o, por lo menos, inadecuado para el objetivo que su obra tenía, que era convencer a un alto cargo de la corona de que debía detenerse la implementación de las Nuevas Leyes.

${ }^{41}$ Plutarco afirmará, en Sobre la paz del alma (6, § 467 c, t. VII, p. 124): "Diógenes fue desterrado: “¡No estuvo tan mal!”, porque comenzó a filosofar después del destierro.” 
Finalmente, como dijimos, el hipernaturalismo llegaba a considerar al animal como un ser más sabio y feliz, y por lo tanto más cercano a la divinidad, que el hombre. Esta tradición teriofílica pudo suponer una importante fuente de inspiración para aquellos autores que quisiesen defender el indio, en una época en la que su "humanidad" todavía estaba en tela de juicio. Según esta perspectiva, la "inhumanidad" del indígena podía suponer una "humanidad" superior, ya que su presunta condición animal no suponía un obstáculo, sino antes bien, un atajo hacia la verdadera virtud. No se trata, claro está, de que Las Casas pudiese llegar a creer seriamente en un argumento de este tipo. Sin embargo, los modos de argumentación de la época, que no eran tan lineales como acumulativos, podían incluir argumentos poco ortodoxos o extemporáneos. Eso será, precisamente, lo que hará Las Casas en su intento por "hacer que el sacrificio humano sea menos extraño, menos excepcional para el espíritu de su lector" afirmando que "ese sacrificio no está enteramente ausente en la propia religión cristiana" (Todorov, 2005: 197).

Por otra parte, siempre existe la posibilidad de una declinación cristiana del cinismo, especialmente frecuente entre los franciscanos de primera hora, algunos de los cuales habrían llegado a pensar que los indígenas no necesitaban esa "policía" con la que la corona española pretendía civilizarlos y redimirlos, sino que era, precisamente, esa exterioridad de la polis entendida como civilización corrompida y corruptora lo que sentaba las bases de su salud corporal y espiritual. No es extraño, pues, que el franciscano Jerónimo de Mendieta llegará a afirmar, en el "Prólogo" al libro segundo de su Historia eclesiástica indiana, que los infieles "de menor talento hayan tenido en su infidelidad mejor policía y gobierno, en lo que es costumbres morales, que el que tienen, siendo cristianos, debajo de nuestra mano" (II, p. 75).

Ciertamente, el cristianismo siempre desechó el aspecto más provocativo e impúdico del cinismo. Con todo, la naturalidad con la que les pareció que los indígenas iban desnudos, defecaban e, incluso, mantenían relaciones sexuales fue destacada en los escritos de los autores más influidos por el humanismo y que, como pretendemos demostrar, no sólo tenían en cuenta el conocido adagio latino naturalia non sunt turpia, sino también toda una serie de motivos naturalistas e hipernaturalistas, convenientemente depurados, procedentes de la tradición cínica. ${ }^{42}$ Recordemos que el naturalismo, presentado, además, en conexión con las figuras de Antístenes y Diógenes, era un elemento esencial de la philosophia christi, tal y como el mismo Erasmo la enunciaba en su Paraclesis-Methodus.

${ }^{42}$ Vale la pena recordar los ataques que el jesuita François Garasse lanzaría, en La doctrine curieuse des beaux esprits de ce temps ou prétendus tels (1623), contra los cínicos presentados por Pierre Bayle en el artículo "Diógenes el cínico", de su Diccionario histórico y crítico, por considerar que éstos vivían "empleando un lenguaje impío y haciendo cosas desagradables que avergonzarían incluso a los tapinambours y a los caníbales" (cit. en Matton, 2000: 341). 
Uno de los hipernaturalistas, infraprimitivistas o animalistas más influyentes será Michel de Montaigne quien, no sólo en "Los caníbales" y "De los carruajes", sino, más aún, en su "Apología de Raimundo Sabunde", pretende darle al ser humano una lección de humildad mostrando la superioridad relativa en lo que respecta tanto a virtudes como a habilidades de los animales respecto de los hombres. A este tipo de animalismo, que ha sido muy poco estudiado, a pesar de haber sido tan extendido como el primitivismo o el naturalismo mismos, Boas lo llamará "teriofilia" y lo definirá como la actitud que considera que "las betias como los salvajes- son más "naturales" que el hombre y, por lo tanto, son superiores al hombre" (1966: 1). Así, para Montaigne, no sólo la razón y la ciencia, como rasgos específicamente humanos, son fuente de muchos males, cosa que también defenderá Rousseau en su Discurso sobre las artes y las ciencias, sino que, a pesar de considerar que la naturaleza provee a todos sus hijos con los medios de defensa y adaptación más adecuados, de modo que el hombre no está ni por encima ni por debajo de los demás animales, defenderá que los animales son superiores a él por saber curarse a sí mismos, por haber enseñado al hombre tantas cosas (la araña a tejer, el ruiseñor a cantar), así como por dar consantes ejemplos de piedad, fidelidad y gratitud, en muchas ocasiones superiores a aquellos de los que parece capaz el hombre. Boas olvida la fuente cínica de estos argumentos para centrarse exclusivamente en la tradición literaria clásica ${ }^{43}$ Sin embargo, Montaigne también seguía, junto con el naturalismo epicúreo y el relativismo escéptico, el hipernaturalismo o teriofilia cínica, hecho que lo dotó de una perspectiva privilegiada para enfrentarse a la alteridad pretendidadmente radical de las culturas indígenas y que, indudablemente, influyó en su modo de contribuir a la construcción colectiva del mito americano del buen salvaje.

Para acabar, digamos que somos conscientes de que, salvo Montaigne y algunos de sus discípulos, la versión más extendida del mito del buen salvaje no alcanza la radicalidad de los cínicos. Éstos jamás hubiesen concebido al indio como una hoja en blanco donde reescribir con mejor letra el cristianismo o la civilización, sino, antes bien, como una forma de vida superior en virtud de su (aparente) ausencia de convenciones culturales y de su (aparente) cercanía a la vida primitiva, natural o,

43 Principalmente, los fragmentos de Filemón y Menando, la epístola 90 de Séneca, algunos pasajes de Ovidio (Metamorfosis, X, 324 y Amores II, xii, 25), el Grilo de Plutarco (t. IX, pp. 337-368), junto con su imitación moderna Circe (1549) de G. B. Belli, o, incluso, el De contemptu Mundi (lib. I, capt. ix) de Innocencio III-, así como el género de las paradojas, cuyo principal representante son las Paradossi (1543) de Ortensio Landi, obra que Montaigne conoció en la tradición de Charles Estienne. (Boas, 1966: 18-19) El hecho de que Boas sólo se fije en las influencias literarias le llevará a pensar que los discípulos de Montaigne, entre los cuales no sólo debemos contar a Estienne Pasquier, Pierre Charron, La Mothe le Vayer o Pierre Bayle, sino también a Rousseau, "se tomaron sus teorías muy seriamente y sin el humor y la tolerancia de su escepticismo." (Boas, 1966: 53) 
incluso, animal. Pero a pesar de que esta radicalidad nunca pudo ser aceptada por el discurso oficial occidental, ya fuese por ser incompatible con el antropocentrismo cristiano, ya fuese por ser incompatible con el progresismo moderno, parece indudable que muchos motivos cínicos, convenientemente adaptados y domesticados, tuvieron una gran influencia en el modo en que Europa se enfrentó a la cuestión del Nuevo Mundo, en general, y a la de las poblaciones indígenas, en particular.

\section{Conclusión}

Son muchos los aspectos que quedan por estudiar acerca de la influencia del cinismo en la construcción de la versión moderna del mito del buen salvaje. Falta mostrar detalladamente qué anécdotas cínicas pasaron de la obra de Diógenes Laercio o Plutarco a las obras de Erasmo, Vives, Moro o Montaigne y cuáles, a su vez, pasaron de la obra de éstos últimos a la de todos aquellos cronistas, religiosos, teólogos, humanistas o filósofos que participaron, de un modo u otro, en la actualización moderna de este mitema. Bástenos, por el momento, notar que en el mito americano del buen salvaje confluyen, además de la tradición religiosa (Adán y Eva como representantes de una candidez original y natural, el genus angelicum de los milenaristas, el tópico de que Cristo predicó a los simples), y de la tradición literaria grecolatina (Hesíodo, Horacio, Ovidio), una tradición propiamente filosófica que incluye, tanto el naturalismo epicúreo y el antiintelectualismo escéptico como el hipernaturalismo o, incluso, animalismo cínico.

\section{BIBLIOGRAFÍA}

ABELLÁN, José Luis.

1976 "Los orígenes del mito del buen salvaje. Fray Bartolomé de las Casas y su antropología utópica", Revista de Indias, nº 36, pp. 157179.

1979 Historia crítica del pensamiento español. II: La edad de oro. Madrid: Espasa-Calpe.

ALCINA FRANCH, José.

1969 Poesia americana precolombina. Madrid: Editorial Prensa Española.

ALMoINA, José.

1966 "La fraternidad cristiana y la labor social de la primitiva Iglesia novohispana", en VV.AA., XXXVI Congreso Internacional de Americanistas. Sevilla, pp. 59-67. 
ANÓNIMO.

2008 Epistolas pseudodiogénicas, en Los filósofos cínicos y la literatura moral serioburlesca, 2 vols., edición de José A. Martín García. Madrid: AKAL, t. I, pp. 391-429.

BATAILlON, Marcel.

1966 Erasmo y España. Buenos Aires: FCE.

BOAS, George.

1966 The happy beast. In french thought of the seventeenth century. Nueva York: Octagon Books.

BORGES, Pedro.

1987 Misión y civilización en América. Madrid: Alhambra.

BRODA, Johanna.

1975 "Algunas notas sobre crítica de fuentes del México antiguo. Relaciones entre las crónicas de Olmos, Motolinía, Las Casas, Mendieta y Torquemada", Revista de Indias, $\mathrm{n}^{\mathrm{O}}$ 35, pp. 123-165.

CAMPS, Victoria y Saturnino ÁLVAREZ.

1999 Historia de la ética, 1. De los griegos al Renacimiento.

Madrid: Crítica.

CARO LÓPEZ, Ceferino.

1998 "Las minas del Perú, concubinas de los ambiciosos. La crítica moralizadora de la conquista de América", Anuario de estudios americanos, vol. 55, $\mathrm{n}^{\circ} 2$, pp. 441-458.

1999 "Que se vuelva el mundo como se estaba. Literatura y religión en el tema americano del Siglo de Oro: la polémica política", Anuario de estudios americanos, vol. 56, $\mathrm{n}^{\circ} 2$, pp. 441-462.

CASAS, Bartolomé de las.

1999 "Contra los perseguidores y calumniadores de los pueblos del Nuevo Mundo descubiertos en el océano (1550-1551)", en Francisco Fernández Buey (ed.), Cristianismo y defensa del indio americano.Madrid: Libros de la catarata, pp. 39-80.

CASTANY PRADO, Bernat.

2013 "Cerdos en el Paraíso: la influencia de la filosofía epicúrea en la construcción del mito del buen salvaje", en Hombres de a pie y de a caballo, Colección "Batihoja", nº 7, 2013, pp. 279-291.

CHESTERTON, Gilbert Keith.

1966 San Francisco de Asís. Barcelona: Juventud. COHN, Norman.

1972 En pos del milenio: Revolucionarios milenaristas y anarquistas místicos de la Edad Media. Barcelona: Barral.

COLÓN, Cristóbal.

1989 Textos y documentos completos, edición, prólogo y notas de Consuelo Varela. Madrid: Alianza. 
CRO, Stelio.

1983 Realidad y utopía en el descubrimiento y conquista de América Hispana (1492-1682). Madrid: International Book Publishers.

DANTE.

1991 Divina comedia. Barcelona: Planeta.

DOWNING, F. F.

1993 "Cynics and early Christianity", en Marie-Odile Goulet-Cazé y Richard Goulet (eds.), Le cynisme ancien et ses prolongements. Actes du colloque international du CNRS (Paris, 22-25 julio 1991). París, pp. 281-314.

DUCH, Lluís.

1992 La memòria dels sants: El projecte dels franciscans a Mèxic. Barcelona: Publicacions de l'Abadia de Montserrat.

EMPÍRICO, Sexto.

1993 Esbozos pirrónicos. Madrid: Gredos.

ERASMO.

1947 Coloquios. Madrid: Austral.

2004 Éloge de la folie. Adages. Colloques. Réflexions sur l'art, l'éducation, la religion, la guerre, la philosophie. Correspondance. París: Robert Laffont.

2008 Adagios del poder y de la guerra y Teoría del adagio. Madrid: Alianza.

FERNÁNDEZ DE OVIEDO, Gonzalo.

1986 Sumario de la natural historia de las Indias, Madrid: Historia 16. GARCÍA GUAL, Carlos.

1996 "La secta del perro", prólogo a Diógenes Laercio, Vidas de filósofos ilustres. Los cínicos, Madrid: Alianza, pp. 9-87.

GARCILASO DE LA VEGA, Inca.

1976 Comentarios reales de los Incas. Caracas: Ayacucho.

GIRARDET, Raoul.

1986 Mythes et mythologies politiques. Paris: Seuil.

GREEN, Otis H.

1969 España y la tradición occidental. Vol. III. Madrid: Gredos.

GueVARA, Antonio de.

1969 Menosprecio de corte y alabanza de aldea. Zaragoza: Editorial Ebro.

1994 Relox de príncipes, en Obras completas de fray Antonio de Guevara. Madrid: Fundación José Antonio de Castro, t. II, pp. 1943.

GuTAS, D.

1993 "Sayings by Diogenes preserved in Arabic", en Marie-Odile Goulet-Cazé y Richard Goulet (eds.), Le cynisme ancien et ses 
prolongements. Actes du colloque international du CNRS (Paris, 22-25 julio 1991). París, pp. 475-518.

HADOT, Pierre.

2006 Ejercicios espirituales y filosofía antigua. Madrid: Siruela.

HORACIO.

2002 Epistolas. Madrid: CSIC.

HURTADO DE TOLEDO, Luis.

1855 Las cortes de la muerte, en Romancero y cancionero sagrados. Madrid: Rivadeneyra.

JIMÉNEZ LEÓN, Marcelino.

2000 “Amor y pedagogía como sátira menipea", en Estudios de literatura comparada, coord. José Enrique Martínez Fernández. León: Universidad de León, pp. 311-337.

JULIANO, Flavio Claudio.

1925 Obras completas. Madrid: Sucesores de Hernando.

KINNEY, Daniel.

2000 "Herederos del perro: la personalidad cínica en la cultura medieval y renacentista", en R. Bracht Branham y M. O. Goulet-Cazé (eds.), KRUEK, Derek. Los cínicos. Barcelona: Seix Barral, pp. 383-429.

2000 "El desvergonzado y la sociedad", en Los cínicos, eds. R. Bracht Branham y M. O. Goulet-Cazé. Barcelona: Seix Barral, pp. 291314.

LAERCIO, Diógenes.

1998 Vidas de los filósofos más ilustres. México: Porrúa.

LAFAYE, Jacques.

1984 Mesías, cruzados, utopias: El judeo-cristianismo en las sociedades ibéricas. México D.F.: FCE.

LISS, Peggy K.

1986 Orígenes de la nacionalidad mexicana, 1521-1556: La formación de una nueva sociedad. México D.F.: FCE.

LOVEJOY, Arthur y Georges BOAS.

1935 Documentary History of Primitivism and related Ideas in Antiquity.

Oxford-Baltimore: Johns Hopkins Press.

LUCIANO DE SAMÓSATA.

1990-2008 Obras, 4 vols., Madrid: Biblioteca Clásica Gredos.

MANUEL, F. E., B. MORENO y P. M. FRITZIE.

1984 El pensamiento utópico en el mundo occidental. Madrid: Taurus.

MARAVALL, José Antonio.

1949 "La utopía político-religiosa de los franciscanos en Nueva España", Estudios Americanos, vol. I, n 2, pp. 199-227. 
1982 Utopía y reformismo en la España de los Austrias. Madrid: Siglo XXI.

MARCO AURELIO.

2005 Meditaciones. Madrid: Gredos.

MARTÍN GARCÍA, José A.

2008 Edición, estudios y notas de Los filósofos cínicos y la literatura moral serioburlesca, 2 vols. Madrid: AKAL.

MARTÍN HERNÁNDEZ, Francisco.

1986 "Humanismo, erasmismo y utopía cristiana en el nacimiento de América", Salmanticensis, nº 33, pp. 55-80.

MARTIN, R. P.

2000 "El acento escita: Anacarsiss y los cínicos", en Los cínicos, eds. R. Bracht Branham y M. O. Goulet-Cazé. Barcelona: Seix Barral, pp. 182-207.

MATTON, S.

2000 "Cinismo y cristianismo en la Edad Media y en el Renacimiento", en R. Bracht Branham y M. O. Goulet-Cazé (eds.), Los cínicos. Barcelona: Seix Barral, pp. 315-345.

MENDIETA, Jerónimo de.

1973 Historia eclesiástica indiana. Madrid: Atlas, BAE, $\mathrm{n}^{\circ}$ 260-261.

MEJ́́A, Pedro.

2003 Silva de varia lección. Ed. Isaías Lerner. Madrid: Castalia. MiLhou, Alain.

1983 Colón y su mentalidad mesiánica en el ambiente franciscano español. Valladolid: Seminario Americanista.

MOLES, John L.

2000 "El cosmopolitismo cínico", en R. Bracht Branham y M. O. GouletCazé (eds.), Los cínicos. Barcelona: Seix Barral, pp. 142-162.

MonTAIGNE, Michel de.

2006 Ensayos, 3 vols. Madrid: Cátedra.

MotoliníA, Fray Toribio Benavente.

2014 Historia de los indios de la Nueva España. Eds. Bernat Castany y Mercedes Serna. Madrid: Anejos de la Real Academia de la Lengua Española.

NUSSBAUM, Martha.

2003 La terapia del deseo. Teoría y práctica en la ética helenística. Barcelona: Paidós.

ONFRAY, Michel.

2002 Cinismos. Retrato de los filósofos llamados perros. Buenos Aires : Paidós.

2008 Las sabidurias de la antigüedad. Barcelona: Anagrama. 
ORDIZ, Javier.

1988 "La utopía del Nuevo Mundo en el pensamiento de Bartolomé de las Casas y fray Bernardino de Sahagún”, Tierras de León: Revista de la Diputación Provincial, vol. XXVIII, nº 71, pp. 1-14.

OVIEDO, Rocío.

1997 "La anécdota en la Crónica de Indias", en Congreso Internacional Italia, Iberia y el Nuevo Mundo. Roma: Bulzoni, pp. 187-206.

PETRARCA.

2003 Triunfos, ed. Guido M. Cappelli. Madrid: Cátedra.

2010 La meva ignorància i la de molts altres. Barcelona: Adesiara. [Las PHELAN, John L. traducciones son nuestras].

1972 El reino milenario de los franciscanos en el Nuevo Mundo. México D.F.: Instituto de Investigaciones Históricas-UNAM.

PLUTARCO.

1986-2008 Moralia, 10 vols. Madrid: Gredos.

RELIHAN, Joel C.

1993 Ancient Menippean Satire. Baltimore: The John Hopkins University Press.

2000 "Menipo en la Antigüedad y en el Renacimiento", en Los cínicos, eds. R. Bracht Branham y M. O. Goulet-Cazé. Barcelona: Seix Barral, pp. 346-382.

RODRÍGUEZ PUÉRTOLAS, J.

1971 "Las cortes de la muerte, obra erasmista", en Homenaje al Profesor William L. Fichter, Madrid, pp. 647-658.

RoMM, James.

2000 "Cabezas de perro y nobles salvajes: ¿cinismo antes de los cínicos?", en R. Bracht Branham y M. O. Goulet-Cazé (eds.), Los cínicos. Barcelona: Seix Barral, pp. 163-181.

SAHAGÚN, Bernardino.

1982 Historia general de las cosas de Nueva España. México D.F.: Fomento Cultural Banamex.

SALISBURY, Juan de.

1984 Policraticus. Ed. Miguel Ángel Landero. Madrid: Editora Nacional. SAN AGUSTÍN.

2007 La ciudad de Dios. Ed. Rosa Marina Sáez. Madrid: Gredos. SAN JUAN CRISOSTOMO.

1958 Contra los impugnadores de la vida monástica, en Tratados ascéticos. Madrid: Biblioteca de Autores Cristianos.

TODOROV, Tzvetan.

2005 La conquista de América. Madrid: Siglo XXI. 
VALDÉS, Alfonso de.

1993 Diálogo de Mercurio y Carón. Madrid: Castalia.

VIVES COLL, Antonio.

1959 Luciano de Samósata en España (1500-1799). Valladolid: SeverCuesta.

VV.AA.

2008 Los filósofos cínicos y la literatura moral serioburlesca. Ed. José A. Martín García, 2 vols. Madrid: AKAL.

ZAVALA, Silvio.

1988 Las instituciones jurídicas en la conquista de América. México: Porrúa.

ZORITA, Alonso de.

1941 Breve y sumaria relación de los señores de la Nueva España, en Nueva colección de documentos para la historia de México, ed. de Joaquín García Icazbalceta. México D.F.: Editorial S. Chávez Hayhoe, pp. 65-205. 